\title{
Visions of Community Comparative Approaches to Ethnicity, Region and Empire in Christianity, Islam and Buddhism (400-1600 CE) (VISCOM)
}

\section{Walter Pohl and Andre Gingrich*}

\section{General aims}

Visions of Community (VISCOM) is an interdisciplinary project funded by the Austrian Research Fund FWF under the SFB (Spezialforschungsbereich) funding line. This includes five project leaders and about 15 other (junior and mid-career) researchers at the University of Vienna and the Austrian Academy of Sciences. VISCOM started in 2011, and has successfully gone through an extension reviewing process in 2014. By consequence, the second funding period runs until February 2019. This format is ideal for in-depth interdisciplinary research in the humanities - eight years offer the opportunity to familiarize each other with current insights, research approaches and methodological problems in the respective disciplines and fields, and to develop workable comparative perspectives. Close long-term cooperation allows addressing issues that have usually been looked at separately: the project looks at svisions ' and concepts of community, and at the shaping of communities on the ground; it studies religious frames of reference in connection with social and political practices; it compares a diversity of selected European and Asian case studies in order to find out which level of qualitative comparison may be adequate in which case; and it combines source-based analyses with theoretical and methodological efforts to enable a broader applicability of the project results. ${ }^{1}$

The leading research question is in what ways ideas and discourses that aimed at constructing spiritual communities and transcending existing social groupings came to influence or legitimize the shaping of particular communities: of empires or territorial polities, of tribes or ethnic groups, of urban or rural populations, but also of monastic and other religious communities. How did complex pre-modern societies conceptualize and construct social coherence, both in society at large, and for smaller groupings within them? VISCOM addresses this guiding intellectual question to a number of spatially and chronologically quite distinct cases in medieval Eurasia: early medieval Europe; medieval South Arabia and neighbouring regions; imperial and post-imperial Tibet in its relationship with Buddhist India; high to late medieval Central Europe; and late medieval Dalmatia. Among others, VISCOM deals with Christian constructions of community in early medieval exegetical and eschatological texts;

\footnotetext{
* Correspondence details: Walter Pohl, Institute for Medieval Research, Austrian Academy of Sciences, Wohllebengasse 12-14, 1040 Vienna, Austria, email: walter.pohl@oeaw.ac.at

Andre Gingrich, Institute for Social Anthropology, Austrian Academy of Sciences, Apostelgasse 23, 1030 Vienna, Austria, email: andre.gingrich@univie.ac.at

1 Pohl, Meanings of Community; Gingrich, Medieval Eurasian Communities.
} 
with forms of identification regarding tribal and Islamic communities in South Arabia; with spiritual texts written in post-imperial Tibetan monasteries; with the production and the uses of an inclusive collection of saints' lives in high and late medieval Austria; or with conflicts and their legal documentation in a fifteenth-century Dalmatian city.

All three suniversal« religions could be used to legitimize imperial rule - in the Christian Roman Empire of Late Antiquity, in the early Islamic Caliphate and in the Tibetan Empire of the seventh to ninth centuries. These were powerful aggregates of universal ambitions, but were also torn by their inner contradictions, and their limits soon became obvious. The three religions thus also supported other - regional, urban, local or ethnic - forms of community. With all due caution, the project goes beyond the textual level to reconstruct the social and cultural context of ways in which communities were simagined،. How were political, ethnic, tribal, territorial, civic communities and identities encoded by systems of belief? How did they interact with spiritual groupings that transcended them? How could particular communities be legitimized and distinguished from others by overarching religious discourses? These questions clearly go beyond binary oppositions such as between theory and practice, or between the religious and the secular. They push toward better methods for understanding past societies in which all sides of these oppositions were deeply entangled, but not simply one and the same.

On a first level, therefore, VISCOM relies on diligent disciplinary source work as a basis for comparative studies. On a second level, existing models for community building and their relevance for identity formation in these societies are critically reviewed, and new models developed where necessary. This is where trans- and cross-cultural comparison becomes essential. So far, comparative studies in these historical fields mostly have operated on a rather general level, often relying on handbook knowledge to assess state-building processes or the forms of religious integration in different societies. The interdisciplinary approach of the proposed project makes a more complex and more differentiated interpretation possible. The aim is not only to gain new insights about the past societies under scrutiny, but also to evolve an improved and up-dated understanding of the problems of communities and identities whether religious, social, ethnic, or otherwise - and of their potential for resistance to, or compliance with imperial polities. On the basis of this focused qualitative comparison, and accompanied by theoretical reflections, questions of comparative methods in interdisciplinary medieval studies in general are addressed. ${ }^{2}$ First results of comparative reflections, also based on an international conference, were published in 2015 in a theme issue of the journal >History and Anthropology.$^{3}$

\section{Project parts}

The first project part (VISCOM PO2: Christian discourse and political identities in early medieval Europe; PL: Walter Pohl) addresses the role of Christianity in the shaping of communities in late antique and early medieval Europe. That was a formative period in which important resources for later developments in the history of Europe were accumulated: eventually, this led to the emergence of a complex political landscape shaped by Christian, ethnic, imperial, civic and territorial identifications. ${ }^{4}$ Contrary to what historians have long believed, the ethnic ('nationalı) identities that were created between c. 300 and c. 1100 AD were 
neither stable nor lasting, although they established models of legitimate polities that could be re-used, for instance by modern nationalism. What developed in the period was a general consensus about the - ethnic and Christian - legitimation of power and about modes of social distinction and integration. A set of differentiated Christian discourses framed political cultures in which the religious sphere was considered (to an extent) as distinct from worldly power and at the same time was seen as deeply intertwined with it. ${ }^{5}$ An important goal of this project part is to grasp these tensions between political and religious elements, often resulting in considerable contradictions but also in many attempts to reach a new balance. We try to think in terms of dynamic tensions rather than in juxtaposed and clear-cut categories, to historicize our concepts, and to root this methodological effort in meticulous source-work. In this respect, the comparison with Islamic and Buddhist societies is immensely valuable to pick scholarly routines of interpretation apart, to ask new questions, and to put the history of the Latin West in its wider intercontinental and Eurasian perspectives. ${ }^{6}$

The second project part (VISCOM Po3: South Arabia between Late Antiquity and Early Modernity, PL: Andre Gingrich) has grouped its main research activities into five topical clusters, including >Demographic diversity and social organization<, >Dynamics between states and tribes`, `Genealogy, historiography, and source criticism`, ১The interconnectedness of religious and tribal visions of community<, and ıIslamic legal visions of community: war, welfare, and taxes`. In its focus on medieval Arabic-Islamic Yemeni history, it has addressed a number of important research issues, such as the specific circumstances of the fairly late emergence of Islamic Zaydi senclaves of learning in the northern plateaus in the eleventh and twelfth centuries with ensuing processes of establishing hypergamy. Of particular interest is the tenth-century author al-Hamdānī, who lived at a crucial time when the Zaydi imamate in the Yemen was but shortly established and certain tribal communities had to reassert their South-Arabianness in opposition to the new religious movement. ${ }^{7}$ Al-Hamdani - especially with his geographic/territorial writing, but also with the genealogical parts of his work al-Iklil - was one of the most prominent figures of this tribal self-assessment. Among other core topics, this project part has addressed the factors underlying the historical longevity of tribal territories in central Yemen. One focus will also be on the extent to which local endogamy and regional isogamy, with a correspondingly strong position of women, provided a key for fairly continuous property relations in agricultural village forms of landholding, thereby perpetuating the acknowledged continuity of communal territorial borders in much of Upper Yemen. Through these social mechanisms, one of the basic forms of rural svisions of community s throughout Upper Yemen's medieval history was maintained and perpetuated with only slow and gradual transformations. ${ }^{8}$

The third project part (VISCOM Po6: Social and Cultural Communities across Medieval Monastic, Urban, and Courtly Cultures in High and Late Medieval Central Europe; PL: Christina Lutter) aims at looking at central research categories of VISCOM - religion, ethnicity, and empire - from a bottom-up perspective relating them to more operative categories of social belonging effectuated >on the ground of local and regional societal levels and in inter-regional relations depending both on personal networks and on institutional affiliations. The

\footnotetext{
Heydemann, Biblical Israel and the Christian gentes.

See Pohl et al., Visions of Community.

Mahoney, Political Construction of a Tribal Genealogy.

Gingrich, Envisioning Medieval Communities in Asia.
} 
focus lies on processes of this type of community-building in the thirteenth and fourteenth century and their political significance in neighbouring regions in the South-East of the Holy Roman Empire - Austria and Styria, Bohemia and Moravia. Shared key questions focused on monasteries, towns/cities, and noble/courtly culture as social spaces where forms of belonging were negotiated. They are approached by means of several case studies drawing on different types of source material (narrative texts; material culture; charters, administrative and economic records). First results of this work make clear that the social spaces proposed as units of analysis were even more entangled both in terms of overlapping narrations and media of community representations and in terms of interacting personal as well as institutional networks than originally supposed. ${ }^{9}$

The fourth project part (VISCOM PO7: Society, Statehood and Religion at the Fringe of the Late Medieval Balkans: Case Studies from Dalmatia; PL: Oliver Schmitt) focuses on Late Medieval Dalmatia whose rural and urban communities are analyzed in two regional case studies (Split and Korčula) on the base of an extraordinary wealth of primary sources. In its theoretical approach, the project part combines the assessment of microhistory with that of "Lebenswelten" (life worlds) in order to provide thick descriptions of how community was enacted in social practice and in discourse. The analysis of published normative and unpublished archival evidence underlines the importance of constitutional patterns of community building, especially the gap between patricians and non-patricians, while religious and ethnic elements did not play a major role. Research concentrated on pastoral communities, and the socio-cultural networks of a patrician dynasty and the family of two peasant leaders. First results offer evidence for a high awareness of various layers of social and constitutional belonging: an intimate knowledge of written local law even with non-patricians, enacting communitarian belonging in numerous cases of petty daily conflicts demonstrates that belonging to and being loyal to communities was essential for structuring Late Medieval Dalmatian society. A close scrutiny of sources reveals, however, that constitutional boundaries between communities were permeable and objects of negotiation - a high degree of community awareness did not exclude social and economic contacts across symbolical boundaries. The interplay of tight socio-constitutional rules and their flexible interpretation in social practice were key elements of the analysis. ${ }^{10}$

The fifth project part (PO4: The Tibetan Empire and the Formation of Buddhist Civilisation in the Highlands; PL: Helmut Krasser $+/$ Vincent Eltschinger) conducts research into the period reaching from the heyday of the Tibetan Empire (seventh to ninth centuries) to the post-imperial context of the Buddhist Renaissance as it gained momentum from the eleventh century onwards. In this latter period especially, the universalist programme of civilisation represented by Buddhism encountered older traditions and principles of community building anchored in a tribal order represented by patrilineal clans. ${ }^{11}$ Until well into the post-imperial period, largely regionally-oriented ancestral lineages formed a fundamental constitutive element of the polities of the Highlands. The tensions arising from this encounter proved to be essential for the way Buddhism established itself in the post-imperial period (eleventh to early seventeenth century), as aristocratic hegemonies based around specific Buddhist

9 Lutter, Vita communis in Central European Monastic Landscapes; Lutter, Social Groups, Personal Relations, and the Making of Communities; Gruber, The City as a Commune.

10 Schmitt, Korčula sous la domination; Schmitt, Addressing Community in Late Medieval Dalmatia. See also Gruber et al., Eine Kulturgeschichte der Überlieferung.

11 Hazod, Tribal Mobility and Religious Fixation. 
monastic networks rose in Central Tibet and beyond. These interrelations between local tradition and Buddhist discourse have thus far been under-represented in modern Tibetology, and VISCOM has enabled the researchers involved to address this question. Based on indepth studies of primary (and hitherto unedited) source texts, they investigate decisive elements of the political, religious and narrative visions of community that established themselves as a consequence of the Empire and Buddhism. More specifically, studying the Sa Skya monastic network in the region of lower Central Tibet has proved exceptionally valuable. By focusing on the corpus of hagiographical texts emanating from that network, and analysing not only the monastic landscapes they represented but also their self-conception and forms of expression, the research undertaken in this context has augmented the project's interdisciplinary methodology and provided comparative insights about medieval monastic communities in differing cultural settings.

\section{Transversal Working Groups}

As regular platforms for interdisciplinary exchange, VISCOM has established transversal working groups, a format that has proven very successful in allowing in-depth comparison. The topics were developed bottom-up on the basis of common interests emerging in disciplinary work. The collaborative volume $>$ Meanings of Community across Medieval Eurasiar assembles substantial results from some of these working groups. The first of these experiences, sketched briefly in the following (and amply treated in the >Meanings of Community volume), has demonstrated the chances, but also the problems of cross-cultural comparison.

\section{A comparative adventure: 'Enclaves of learning, ${ }^{12}$}

The comparison between Christian and Tibetan monasteries emerged directly from work done in the project parts. In a next step, it led to the inclusion of the so-called hijra in Yemen, named after the retreat of the inmates, who often claimed descent from the Prophet Muhammad's family. Medieval Southwest Arabian hijras are a largely understudied phenomenon, and have rarely been compared to Western or Tibetan monasteries. At first glance, parallels between these three forms of community impose themselves: localized, self-styled communities, at least notionally bounded against the outside world, focusing on spiritual practice and the transmission of - mostly sacred - knowledge, concerned with the development of religious doctrine, under the protection of surrounding aristocrats or tribal leaders for whom they fulfil religious, legal and social functions, prevalently funded by pious donations, and connected to but also in competition with similar institutions. But the comparison also runs into problems that the working group soon had to face.

The term monastery comes from the Christian tradition, where it coexists with claustrum, cloister, which underlines its boundedness. Already the eighteenth-century Jesuit missionaries in East Asia noticed the striking similarities of Buddhist >monasteries ' with Western ones. Tibet, however, has no single term for monastery; apart from sgompar there are several other terms which underline different aspects of these institutions. Hijras are in many respects a functional and legal equivalent, but can hardly be called >monasteries lines. It also has to be taken into account that all three forms of religious community saw much variation and changed over time, which also becomes obvious by confronting eighth/ ninth century and thirteenth/fourteenth century monasteries in the West. How can the range of phenomena to be compared be conceptualized, and distinguished from similar centres of

12 See Kramer, Spiritual Communities across Medieval Eurasia, and the other articles in the same section; Hovden and Kramer, Wondering about Comparison. 
learning such as cathedral schools or madrasas? After some discussion about possible names for the working group, senclaves of learning` was chosen to highlight the distinct character of these marked-out areas, and their role in knowledge transfer and learning. However, this label is also debatable, as became clear in the course of the work: boundedness constitutes a point of comparison - how open were the respective communities, legally or pragmatically? In Tibetan Buddhist and European Christian monasteries, membership implied renunciation of the world for life. But that did not impede various contacts with the outside world. Monks and lamas performed services for the surrounding laity and local rulers and visited their households. Similarly, Christian monasteries have been described as spowerhouses of prayer in a network of exchanges with the surrounding population.

One pragmatic difficulty that arose was the rather different character of the sources, and their very uneven accessibility, which shape our view of these medieval communities. In Tibet as in Yemen, only a fraction of the existing written sources have actually been studied; in both areas, access is currently hampered by the political situation. Early medieval Europe offers mostly well-edited texts, whereas late medieval sources are extremely numerous. On the whole, a great variety of texts shed light on medieval European monasteries - not least, charters and other documents about their economic basis and their transactions with the outside world, a type of source mostly lacking for medieval Yemen and Tibet. What all three cultural spheres have in common are the biographies of founders, members, patrons and holy men, which can broadly be defined as 'hagiography<. Christian saints' lives mostly abound in stories about miracles, often at the saint's grave. Tibetan texts emphasize a saint's previous rebirths and his relations to a master and his spiritual lineage in order to guarantee the purity of spiritual knowledge. The right Islamic tradition, and its defence against other Islamic currents, takes centre stage in many Yemeni biographies. The Asian traditions focus more on the key role of the spiritual teacher than most Western monastic texts. Christian monasteries reflected more about their institution as such, its spiritual practices, its rule and organisation and its position in society. Thus, the uneven transmission of sources can in itself yield interesting comparative insights.

One Transversal Working Group deals more generally with 'Spiritual Visions of Community: Texts, Sites and Interactions'. Among others, this group addresses the overarching concepts of religious community, such as the spopulus Christianus a and the summar. Both terms could also be used for much more particular communities - for instance, the population of a specific diocese or parish in the West, or single peoples or tribes (even non-Islamic Turks) in early Islamic usage. One of the more specific topics of the working group is >Cross-Cultural Perspectives on the End of Times ${ }^{13}{ }^{13}$ Eschatological ideas were common in all three religious spheres, and some comparative research has already been done in the field. What is interesting in our project design is that we can compare Christian and Islamic ideas of the end of times, both of which were based on the Old Testament and developed in an interesting conjunction with the Alexander romance, with Hindu and Buddhist ones set in quite another context, and based on cyclical perceptions of time. What was the impact of eschatological expectations on feelings of community? Among others, the apocalyptic peoples Gog and Magog could accentuate the othering of enemies, specifically steppe peoples, in both Christian and Islamic contexts. 
Another Transversal Working Group addresses Urban Communities and Non-Urban Sites and Centres. One often-noted difference between Western European and Asian cities has, at least since Max Weber, been the notion of a civic community regulated by law and administered by autonomous bodies, such as city councils, mostly absent from the East. ${ }^{14}$ Still, there is more to the comparison, and some relevant themes have already been explored, for instance, functions, urbanism and spatial organization. The Transversal Working Group sTribes and Ethnicity r raises comparative questions that have hardly been addressed so far. Why are some tribal systems so time-resistant, for instance in contemporary Yemen, and can pose serious problems to states in the area? Why could ethnicity become a basis for state-building elsewhere, such as in early medieval Europe? Why did it matter so little in other contexts (such as late medieval Dalmatia)? In what ways religions endorsed or channeled ethnic identities and their political uses obviously differed considerably between our case studies. One issue also raised in this context is sKinship and Gender «. Genealogical thinking is an important way in which sedentary and pastoral humans have envisioned social relations and world orders. It can be applied, in a narrower sense, to kinship and descent, but also in a wider sense to a range of other phenomena - for instance, to the spiritual genealogies of Tibetan Buddhist lamas or to the pictorial representations of the filiation of late medieval Christian orders. Significant differences in the role of genealogies emerge between early medieval Europe and the early Islamic world. ${ }^{15}$ In South Arabia, tribal leaders often saw their groups as connected to eponymous tribal ancestors, which supported notions of common origins for certain tribes, whereas in the West, this was only sometimes achieved by means of a distant connection with the sons of Noah. In early medieval Europe, genealogies are mainly transmitted for ruling dynasties and the high aristocracy, if at all, whereas the genealogical interest is much better documented in the Islamic World. The frequent political uses of ethnicity in the West, and the relative insignificance of genealogical constructions of social relations may therefore just be two sides of a coin.

In terms of project design, the VISCOM approach to comparison can be summed up as follows:

The case studies to be compared are conducted by specialists within their disciplinary context on the basis of original sources.

We do not compare Christendom, the Islamic and the Buddhist World, or the respective religions, as a whole, but have selected more specific and regionalized case studies.

Comparison requires some understanding of the ways in which conclusions were reached on the basis of the sources in all cases compared.

The phenomena to be compared are constituted in the course of an interdisciplinary dialogue on the basis of preliminary results from the disciplinary studies within the thematic frame of VISCOM.

Modern scholarly concepts are historicized by taking contemporary perceptions and 'native knowledge' into account.

Careful comparison therefore is an open process, and takes time.

There should be the opportunity to reflect on the comparative process and its methodological implications as an integral part of the research. 
The ambition of VISCOM is to cover a broad range of historical research from work with the sources, their critique and their interpretation, to addressing large issues with the help of comparative studies, accompanied by methodological reflection. 


\section{References}

Gingrich, Andre, Envisioning Medieval Communities in Asia: Remarks on Ethnicity, Tribalism, and Faith, in: Pohl et al., Visions of Community in the Post-Roman World (Farnham, 2012) 29-41.

Gingrich, Andre, Comparative Methods in Socio-Cultural Anthropology Today, in: Richard Fardon, Oliva Harris, Trevor H. J. Marchand, Cris Shore, Veronica Strang, Richard Wilson and Mark Nutall (eds.), Handbook of Social Anthropology, vol. 2, (Los Angeles, 2012) 201214.

Gingrich, Andre, Methodology, in: James G. Carrier and Deborah B. Gewertz (eds.), The Handbook of Sociocultural Anthropology (London, 2013) 107-124.

Gingrich, Andre and Lutter, Christina (eds.), Visions of Community. Comparative Approaches to Medieval Forms of Identity in Europe and Asia, Special Issue: History and Anthropology 26/1 (2015).

Gingrich, Andre, Medieval Eurasian Communities: Methods, Concepts, Insights, Hovden et al., Meanings of Community across Medieval Eurasia (Leiden, forthcoming).

Gruber, Elisabeth, Lutter, Christina and Schmitt, Oliver, Eine Kulturgeschichte der Überlieferung. Mittel- und Südosteuropa 500-150o (Vienna) forthcoming.

Gruber, Elisabeth, The City as a Commune, Hovden et al., Meanings of Community across $\mathrm{Me}$ dieval Eurasia (Leiden, forthcoming).

Hazod, Guntram, Tribal Mobility and Religious Fixation. Remarks on Territorial Transformation, Social Integration and Identity in Imperial and Early Post-Imperial Tibet, in: Walter Pohl, Clemens Gantner and Richard Payne (eds.), Visions of Community in the Post-Roman World (Farnham, 2012), 43-57.

Heydemann, Gerda, Biblical Israel and the Christian gentes. Social Metaphors and the Language of Identity in Cassiodorus' Expositio psalmorum, in: Walter Pohl and Gerda Heydemann (eds.), Strategies of Identification. Religion and Ethnicity in Early Medieval Europe (Turnhout, 2013) 143-208.

Hovden, Eirik, Kramer, Rutger, Wondering about Comparison: Enclaves of Learning in Medieval Europe and South Arabia - Prolegomena to an Intercultural Comparative Research Project, Networks and Neighbours 1 (2014) 20-45. Retrieved on 8 June 2015: http://networksandneighbours.org/index.php/n/article/view/33/23.

Hovden, Eirik, Lutter, Christina and Pohl, Walter (eds.), Meanings of Community across Medieval Eurasia (Leiden) forthcoming.

Kramer, Rutger, Introduction: Spiritual Communities across Medieval Eurasia, in: Hovden et al., Meanings of Community across Medieval Eurasia (Leiden, forthcoming).

Lutter, Christina, Social Groups, Personal Relations, and the Making of Communities in Medieval vita monastica, in: Jörg Rogge (ed.), Making Sense as Cultural Practice. Historical Perspectives, Mainzer Historische Kulturwissenschaften 17 (Bielefeld, 2013) 45-61.

Lutter, Christina, Vita Communis in Central European Monastic Landscapes, in: Hovden et al., Meanings of Community across Medieval Eurasia (Leiden, forthcoming).

Mahoney, Daniel, The Political Construction of a Tribal Genealogy from Early Medieval South Arabia, Hovden et al., Meanings of Community across Medieval Eurasia (Leiden, forthcoming).

Pohl, Walter, Gantner, Clemens and Payne, Richard (eds.), Visions of Community in the PostRoman World. The West, Byzantium and the Islamic World, 300-110o (Farnham, 2012). 
Pohl, Walter, Introduction: Strategies of Identification. A Methodological Profile, in: Walter Pohl and Gerda Heydemann (eds.), Strategies of Identification. Religion and Ethnicity in Early Medieval Europe (Turnhout, 2013) 1-64.

Pohl, Walter, Christian and Barbarian Identities in the Early Medieval West: Introduction, in: Walter Pohl and Gerda Heydemann (eds.), Post-Roman Transitions: Christian and Barbarian Identities in the Early Medieval West (Turnhout, 2013) 1-46.

Pohl, Walter, Meanings of Community: introduction, in: Hovden et al., Meanings of Community across Medieval Eurasia (Leiden) forthcoming.

Pohl, Walter, Genealogy: a Comparative Perspective from the Early Medieval West, Hovden et al., Meanings of Community across Medieval Eurasia (Leiden) forthcoming.

Schmitt, Oliver Jens, Korčula sous la domination de Venise au 15e siècle, Les conférences du Collège de France [e-book] (Paris, 2011). Retrieved on 8 June 2015: http://books. openedition.org/cdf/1501.

Schmitt, Oliver Jens, Addressing Community in Late Medieval Dalmatia, Hovden et al., Meanings of Community across Medieval Eurasia (Leiden) forthcoming.

Wieser, Veronika, Zolles, Christian, Feik, Catherine, Zolles, Martin, Schlöndorff, Leopold (eds.), Abendländische Apokalyptik. Kompendium zur Genealogie der Endzeit (Berlin, 2013).

Wieser, Veronika (ed.), Making Ends Meet: Cross-Cultural Perspectives on the End of Times in Medieval Christianity, Islam and Buddhism (Berlin) forthcoming. 